\title{
The 19th century traditional houses of the Banjar Islamic (Muslim) community: a display of power
}

\author{
I. Marwoto \\ Department of Archaeology, Faculty of Humanities, \\ Universitas Indonesia, Indonesia
}

\begin{abstract}
As mentioned by Christopher Tilley, a house can be a medium to do negotiations among the individuals and their community. The house can become a site to collect and display cultural capital in terms of individual relations with others to place themselves socially. Rumah Bubungan Tinggi which I researched is a traditional house of the Banjar Islamic Malay Kingdom in Banjarmasin, South Kalimantan, functioning as one where kings have lived. According to the research which has been conducted, there are just about seven wooden houses with rich Islamic caligraphy. The objective of the research is to reveal some facts that this Rumah Bubungan Tinggi as a material culture is used to display those who live in the houses and expose their social power in identity contestation.

Keywords: Rumah Bubungan Tinggi, Islam, Banjar Kingdom, display, identity.
\end{abstract}

\section{Introduction}

As stated by Shank and Tilley [1], the discussion on power according to the archaeology perspective has so far been related to ranking and control. Power is seen as something owned and moving in a top-down manner in a community. This paper will discuss power in a different perspective, meaning that power is seen from something which is not owned by an institution, but is a result of individual activities in any social activities. Power is not something which is an imposing and repressive thing but a positive one, instead. Foucault [2] states that there is no power without resistance, meaning that power is everywhere but it is in line with resistance. This research studies how public resistance takes place in daily activities. Scott in Smith [3] argues that the concept of infra-politics can be 
interpreted that the sub-ordinate's struggle is involved in cultural and political expressions. This concept can be used to have a look at how power worked in the daily activities in the past and how identity was displayed.

The Banjarmasin society is a society living along the river because they live on two rivers, Martapura and Barito; their houses are located on these rivers. Nearly the whole building of both houses and public buildings are made of wood, such as ironwood and wooden girder as foundation piles driven into the river. The forms of traditional houses of the Banjar community vary and the shapes of the structures illustrate the social status of their inhabitants. Rumah Bubungan Tinggi in the Islamic Kingdom of Banjar is considered as the house used by the sultans. The structure form is one of the ten types of Banjar home found. These traditional houses of the Banjar community can be seen as a material culture that can demonstrate the power and the display of the more prevalent community. As presented by Tilley [4], these structures can be considered as a medium for negotiation between the individual and society. These residences can also be a site for collecting and displaying "cultural capital" in individual relationships with others to social position themselves.

Diverse forms of traditional houses as well as a variety of ornaments decorating certain parts of these Banjar community houses can serve as a way to maintain the social hierarchy and identity. As presented by Smith [3], decoration is a way to show one's wealth. Similarly, the display also is the arena of challenge and resistance. In the Banjar community, it is clear that there is a relation between the form of the house with its inhabitants. The shape of the house for those who have more power have more complex shapes and often have an assortment of ornaments, while building houses for the common people have simple shapes and lack ornamentation. Rumah Bubungan Tinggi is a house which was originally owned only by the royal family and the nobility but when the Sultanate of Banjar was destroyed by the Dutch in the early 19th century, the wealthy merchants who originally were only allowed to have palimbangan and joglo home-types could opt to have this type of Rumah Bubungan Tinggi to show and display power and identity. This paper will discuss how Rumah Bubungan Tinggi in Banjar people can demonstrate and display the power and identity. In relation to the discussion of the home as an arena of power and display, the ornaments contained in Banjar traditional houses are considered to be the focus in this study. Ornaments in this case are seen as ones of the expressions of power and a means of identity formation.

\section{Banjar houses as material culture}

The term form of material culture diversity in the science of archaeology is commonly used to refer to artefacts or objects of cultural communities in the past. The studies on the material culture were performed by Woodward [5] that explore various approaches that can be used to study and understand the culture of the material. In addition, Hodder [6] shows that the studies related to how material culture is interpreted and re-interpreted. 
This traditional house can be categorized as material culture which is a symbolic representation of the Banjar people. Traditional homes and their various components can provide a snapshot of how people look at their lives. Leone in Hodder [7] states that the symbols that exist on some elements of the house can identify the relationship between power and domination. Meanwhile, Rapoport [8] explains that the diversity of house style is primarily determined by various factors such as socio-cultural factors, namely the values, the family, the position of women, privacy and social intercourse, and the response to "basic needs."

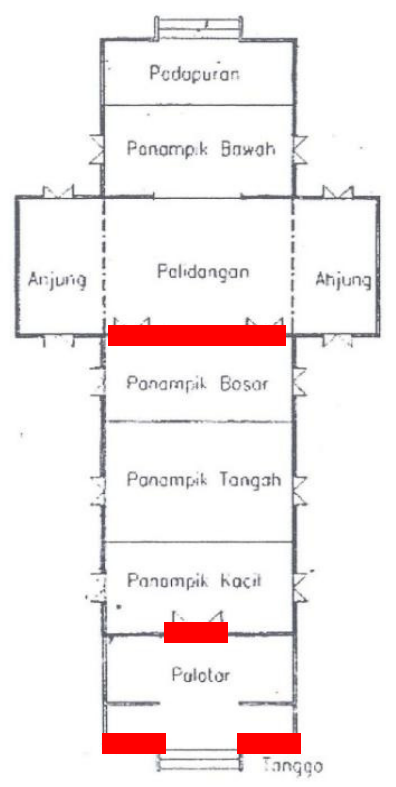

: with ornaments

Figure 1: Blueprint of Rumah Bubungan Tinggi and parts of the house with ornaments.

Rumah Bubungan Tinggi form in the kingdom of Banjar according Pakhri [9] is a house inhabited by the Sultan. This type of building, according to Seman and Irhamna [10], is the oldest type of Banjar traditional house.

There are seven Rumah Bubungan Tinggi studied as follows: 1. Rumah Bubungan Tinggi in the Telok Selong village, Martapura District; 2. Rumah Bubungan Tinggi in Banjarmasin; 3. Rumah Bubungan Tinggi in Kandangan, South Hulu district; 4. Rumah Bubungan Tinggi in Marabahan (2 houses); 5. Rumah Bubungan Tinggi on the river Jingah; and 6. Rumah Bubungan Tinggi in the palace, Martapura. The one to be discussed is the one in Telok Selong because the building is still in good working condition and has the most complete spatial arrangement (see figure 2). 


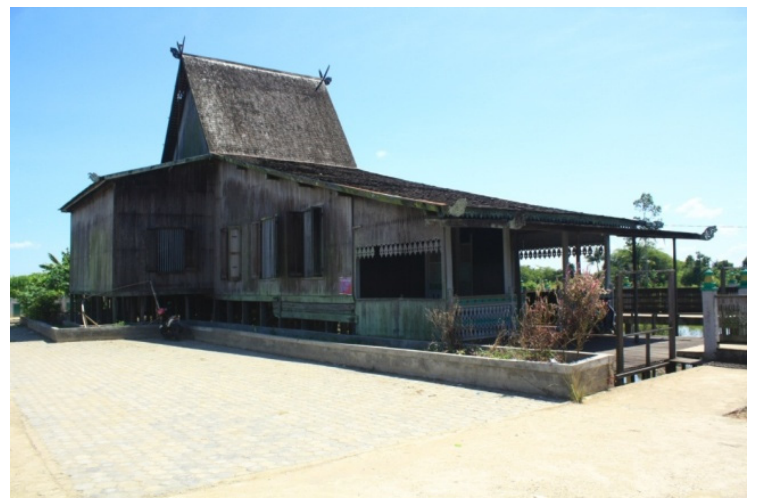

Figure 2: Rumah Bubungan Tinggi in Telok Selong, Martapura.

Rumah Bubungan Tinggi has some spaces that extend from the front to the back of the house: palatar, small panampik, large panampik, palidangan, lower panampik and padapuran; on the left side and the right space of palidangan are anjung kiwa room and right anjung (see figure 1). The length of the longest building is approximately $32 \mathrm{~m}$ and its width of approximately $14 \mathrm{~m}$ and building height ranging from $1.60 \mathrm{~m}$ to $2 \mathrm{~m}$. The composition of the Rumah Bubungan Tinggi is as follows:

a. Palatar: the first room and an open space with its roof. To reach this chamber, we can use a staircase. In general, the front side and the left and right sides of palatar has a constellation cage that serves as a safety fence and decoration. On the roof above this room there are ornaments called pilis. These ornaments are shaped like ropes and according to some experts it is stiliran of dragon head shape (see figure 4).

b. Small panampik: a room after palataran. At the end of this room is the entrance to the large panampik. The floor space is higher than in Palatar room floor and a raised floor's periphery. In this section there is a guardrail called cage constellation generally ornamented.

c. Large panampik: a small room after small panampik. At the top of the door are ornamented tendrils of flowers and leaves, double-layered doors, exterior doors ornamented with flowers. This space is higher than the small panampik floor. After opening the door there is a flat floor covering openings of the doors, then there is another step as the floor is higher than the flat floor. In this room there are two poles and are three windows lining the wall of the left and right given window bars of the odd number from very strong ulin wood. In this room there is a wall named tawing halat the next room is palidangan. Tawing halat has two doors on the left and right sides with the entire surface ornamented among flowers, bapintal rope and calligraphy (see figure 8). Large panampik space is the most widely ornamented space in between the space already described. After this bazaar room is the palidangan chamber. 
d. Palidangan: a wider space in which a family do their daily activities. To enter this room there are two doors on either side of the base of the base tawing halat whose doors are higher than the surface of the floor because there is a field which is the part of the bottom tawing halat with its height of approximately $40 \mathrm{~cm}$, so as to enter the space we should step higher palidangan. Palidangan floor is as the same height with bazaar penampik and all the floor of this house uses wood ulin. Based on the interview with one of the owners of this house, Mrs. Fauzia, in the past, the floor of this house had a mat to sit on. When a family member passes away, the body will be washed in one corner of this room.

e. Right anjung: a space on the right palidangan functioning as a children's bedroom with iron canopy bed and a wardrobe. As a barrier between the room palidangan and right anjung is a higher floor of the floor palidangan. On the front and back of the right anjung is a window with bars.

f. Left anjung/anjung kiwa: a space on the left palidangan as an old man sleeping area by a canopy bed as a barrier between the room anjung and left palidangan with higher floor than palidangan.

g. Pingitan (seclusion) room: This room is located above the lower panampik room after the palidangan room. To get into this space we can go there through small stairs and small door in the wall to the lower panampik space. In this room are beds and equipment for girls to be married. Based on interviews with homeowner, Mrs. Fauzia, five days before the marriage, a girl do a batimung (steam bath) and scrub in this space. Steam bath equipment, such as the form of containers of pottery, are still kept in the house.

h. Lower panampik: This space is located after palidangan room and the floor is lower than that of palidangan. To enter this panampik space, there is is a door in the rear of palidangan and there are stairs. In this room there is a storage area of rice.

i. Padapuran: after the lower panampik, there is padapuran which functions as the kitchen of this house. In this room there is a window near the stove and the exit door on the right and a table to put the furnace on it. The habit of the Banjar community is to put stuff on the table instead of on the floor.

\section{Ornaments as display and power}

In the 16th century, a kingdom in South Kalimantan, namely the Sultanate of Banjar which replaced the Islamic empires Dipa State and State Daha, emerged. Some experts explain $[11,12]$ that the Sultanate of Banjar initially was ruled by the Sultan of Samudra who had the title of Sultan Suriansah who defeated his uncle with the help of Sultanate Demak in Java.

According to van der Ven [13], the Banjar community can be divided into five segments of society, namely: 1. Nobility Group; 2. The Big Man Group; 3. The Ulama; 4. People; and 5. Pandeling (people spout). The nobility is still the sultan family, usually with titles like Prince, Princess, Raden, Gusti and Andin. Most of the big man groups are the ones who held the rank of nobility as 
appointed by the Sultan as officers in the Sultanate such as Kiai and Demat. This appointed degrees should not be passed down to their offspring. In general, they imitate the way of life of royal family which is different from that of ordinary people. The scholars are the mufti, the prince and master teachers whose positions as religious elites. The common people are those groups as traders, farmers, fishermen and craftsmen; while pandeling class is the lowest class because they have lost their independence due to unability to pay their payable accounts.

The Banjar Kingdom had fairly broad powers covering nearly the entire island of Borneo now, even the kingdom of Kutai in East Kalimantan was his realm. However, the Sultanate of Banjar in the early 20th century could be controlled by the government of the Netherlands [11, 12]. Smith [3] reveals that displaying himself/herself with the wealth of a person is a way of showing the power to maintain the existing social system. Personal display is an arena in which hierarchy in the community can be a challenge and can get resistance of society. In connection with the discussion of the home as an arena of power and display, this study focus is of the ornaments contained in Banjar traditional house. The house that shows ornamentation is an expression of power. Ornaments in is case is a form of decoration that is used in Banjar house building.

Based on this study it appears that the pattern placement of ornaments of Rumah Bubungan Tinggi is located on the outside of the house, on the roof, panampih anjung, part of the front fence and entrance. Meanwhile, in the house ornaments are on poles and wall space of palidangan called tawing halat in space of large panampik. The ornaments cannot be found after large panampik. For that reason, ornaments can just be found in the rooms where guests are accepted.

\subsection{Ornaments on the exterior of bubungan tinggi}

\subsubsection{House roof}

On the roof of the house there are ornaments called kites on both ends of the pitched roof with cross position. Generally, there are only two kites intersected at the end of the roof. These kites are decorated with plant motifs, but some also have seven rows of kites like those in Kandangan. Ornaments on the roof of the houses are vernacular as a symbol of social status, wealth and fertility [14]. Banjar home is still under the influence of betang house of the Dayak community in the interior of Borneo where home is a representation of the natural upper, middle and lower nature of nature. Upper nature is described as the presence of bird ornaments on the roof of the house, where people live in the middle between the upper world and the underworld, while the sub consciousness is represented by the dragon ornament $[15,16]$. Ornaments kite resembles a bird's wings in a flying position, so it is possible that this ornament also represents the upper world. On the other hand, ornamental birds can also be seen as an ornament that marks a high social status, as stated by Domenig [14]. Besides ornaments kite on the roof of the house, the house is also decorated with ornaments consisting of ropes as considered a distilled bird motif (see figure 4). 
The towering roof is considered to be a sacred mountain in the world above where Mahatala stays symbolized by the hornbill. The lower house is the symbol of the underworld controlled by the wife of Mahatala called Jata. The lower world is woman-like, cold with completely unambiguous ones, life and death, war and peace and fertility [17].

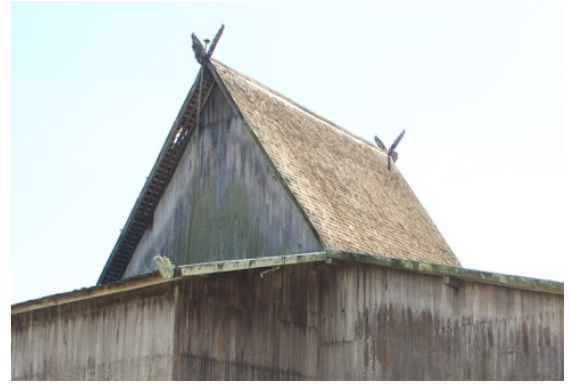

Figure 3: Kite ornaments in Telok Selong.

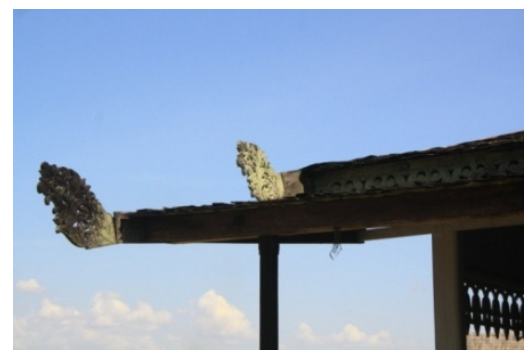

Figure 4: Ornaments of distilir birds.

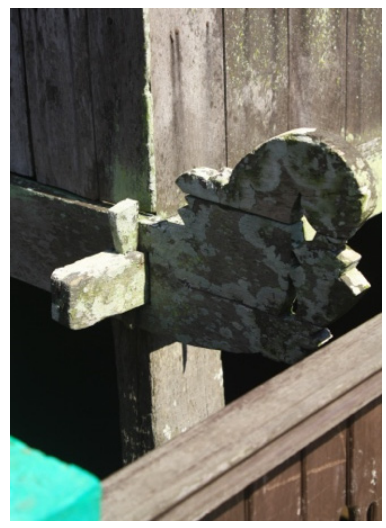

Figure 5: Pilis at waist of Rumah Bubungan Tinggi Telok Selong. 


\subsubsection{Kandang rasi}

At the front of the room there is a small panampik fence enclosure called kandang rasi (constellations). This fence is given in the form of floral ornaments. These ornaments on the cage constellation have a variety of ornaments of flowers arranged along the fence and colour (see figure 6). All Rumah Bubungan Tinggi have the ornaments on the constellations.

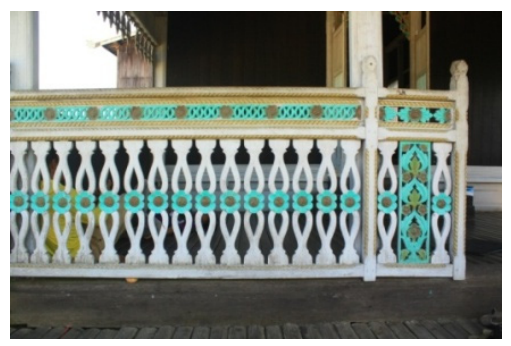

Figure 6: Kandang rasi at Rumah Bubungan Tinggi, Telok Selong.

\subsubsection{Lawang hadapan}

The entrance is ornamented with motifs of flowers as well as at the top of the door frame. Almost all Rumah Bubungan Tinggi have an entrance which is ornamented with a variety of florals. Each house has typical ornaments on entrances but all ornamental matters are in the forms of flowers and vine leaves.

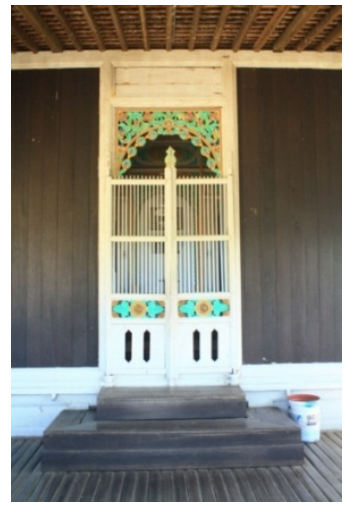

Figure 7: Lawang hadapan di Telok Selong.

\subsection{Ornamen di bagian dalam rumah}

\subsubsection{Tawing halat}

Tawing means wall and halat means separator. Tawing halat is the chamber wall of large panampik restricting this room from palidangan as a private space. Tawing halat is a wall that has a door on the right side and the left side as the door to enter and exit the palidangan room and the large panampik room. 


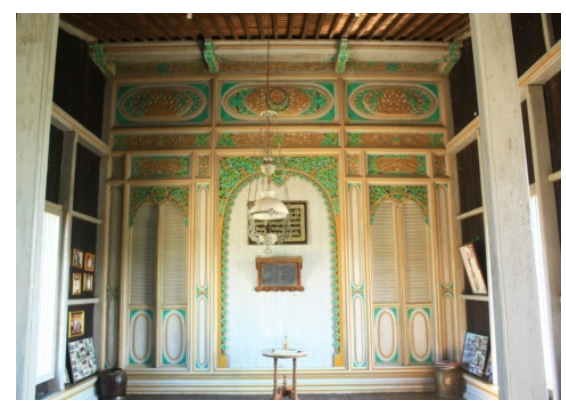

Figure 8: $\quad$ Tawing halat, di Telok Selong.

Tawing halat has beautiful ornaments and in this space guests and the life ceremonies, such as marriage, etc., take place.

Tawing halat is ornamented with calligraphy, vine leaves and flowers. In general, calligraphic ornamentation is in the form of sentences: La IllahaIllalah Muhammad Rasulullah. On the door there is an oval frame made of bapintal rope. At the bottom of tawing halat, there is a high enough frame measuring 40 $\mathrm{cm}$ called watun langkahan. It is known as watun langkahan, according to Seman and Irhamna [18], because those who want to enter tawing halat should pass through this watun. Tawing halat in large panampik space is an important part of the house Banjar because this wall are crafted with various ornaments. In the middle of tawing halat is the most important part in a ceremony. Anyone sitting in the middle is a highly respected person, such as family heads, scholars, etc. The grandeur of a house is seen from the beauty and space of tawing halat and large panampik for another room after room large panampik generally is not ornamented.

Based on this study, it appears that there are ornaments on the exterior and interior of the house. On the outside of the home, more ornaments are placed on the front of the house as the enclosure constellation, entrances and windows and at the foot of the outer wall, and on the roof itself like a kite on a Rumah Bubungan Tinggi. Meanwhile, inside the house, ornaments are simply placed in the room large panampik mainly on tawing halat. The forms of ornaments on the inside of the house are vine leaf tendrils and flowers and rope motif bapintal, sun motif and Arabic calligraphy.

By and large, as a sultanate, the Banjar community has started from the highest hierarchy as king and the nobility of the royal family to ordinary people. The forms of the houses initially showed the hierarchy of society, Rumah Bubungan Tinggi was the home of the king. An explanation of the designation of the house in Banjar is stated in Banjar poem saying that Rumah Bubungan Tinggi is the place for kings. Heather Beaudry in [19] discloses the use of the type of house that becomes a marker of social class hierarchy as an expression of class affiliation and class pride. The last Banjar king, Sultan Tanjid, ruling in the years 1857-1859, was mentioned to stay in a house Rumah Bubungan Tinggi overlooking the Martapura River [20]. 


\section{Display and identity}

Such a situation changed when the kingdom of Banjar collapsed and was controlled by the Dutch in the early 19th century, and groups of kings and nobles who had been rich became poor because of wealth and the land confiscated. The position of the nobility was replaced by the traders who had their own ships to sail throughout Indonesia, especially Java and Singapore [20]. Based on interviews conducted in this study, most Rumah Bubungan Tinggi are owned by the family of merchants, such as merchants of diamond, clothing, wood, and descendants of Arab traders. An example is the Rumah Bubungan Tinggi in Telok Selong owned by a family of diamond merchants.

The change in the Banjar community occured after the end of the empire Banjar destroyed by the Dutch in the early 19th century. The wealthy merchants who were originally only allowed to have palimasan and joglo home can opt to have this type of Rumah Bubungan Tinggi. Banjar Sultanate's destruction have changed the order of life, including the order of who gets to stay at joglo form and palimasan houses to be able to own Rumah Bubungan Tinggi originally belonging to the royal family and royal officials.

According to Longhurst et al. [21] a person's identity is formed through relationships that continue to happen to other people, and also with space. In addition, people can make a choice how to display their credentials depending on where they are and who they are. The merchant class who feel more power and economic capital after the destruction of the kingdom of Banjar have chosen to own Rumah Bubungan Tinggi with a variety of ornaments just displayed on the outside of the house and some are just in tawing halat inside the house as a space to display their identity.

As the Banjar Kingdom which is an Islamic empire, the Islamic identity is also displayed on a Rumah Bubungan Tinggi owned by merchants with calligraphy ornaments found in the house that is in the room large panampik on tawing halat. The exterior of the house does not have Arabic calligraphy ornament but rather on the vine flowers and leaves. Only one house that uses Arabic calligraphy ornaments on the exterior of the home is rumah tadah alas in Malay village owned by a Muslim clergy (ulama). This house type has two separate entrances and on each top of the door there is the Arabic calligraphy containing prayers for the safety of residents. The ornaments are used in the form of flowers and leaves and bapintal tendril strap and this can also be associated with Islam in which the ban on the depiction of living beings.

\section{Conclusion}

The results of the analysis of the role of material culture in the Banjar community in the 19th century is an attempt to understand the identity of a society to reflect on how the choices are determined by the community. The focus of the research is mainly historical research mostly paying attention to the role of the elite [22] through the study of material culture, and we can see the other side, that is ordinary people. This research on material culture, namely 
ornaments in traditional houses of the Banjar community, does not merely find the data as the secondary ones but as important ones to materialize social power and resistance identity. The result of research interpretation plays an important role to see how the material culture, in this case Banjar home ornaments, can be seen as a tool to display itself as a means to convey the power of social contestation of identity, namely a new identity called identity resistance.

\section{References}

[1] Shank, M. \& Tilley, C., Social theory and archaeology, Oxford: Polity Press, pp. 61-78, 1987.

[2] Foucault, M., Power and Knowledge: Selected interviews and other writings, 1972-1977, ed. Colin Gordon, New York: Pantheon Books, 1980.

[3] Smith, S. V., Materializing resistant identities among The Medieval peasantry. An examination of dress accessories from English rural settlement sites. Journal of material culture, 14(3), pp. 309-332, 2012.

[4] Tilley, C., Introduction: identity, place, landscape and heritage. Journal of material culture, 11(1-2), pp. 7-32, 2006.

[5] Woodward, I., Understanding material culture, London: Sage Publication Ltd., 2007.

[6] Hodder, I. (ed), The meanings of things, Material culture and symbolic expression, London: Harper Collins Academic, 1989.

[7] Hodder, I., The interpretation of documents and material culture. Collecting and interpreting qualitative materials, ed. Denzin \& Lincoln, London: Sage Publications Ltd, pp. 155-175, 2003.

[8] Rapoport, A., House form and culture (Foundations of cultural geography series), Englewood Cliffs, N.J.: Prentice Hall, 1969.

[9] Anhar, P., Inventarisasi arsitektur Banjar, Banjarmasin: Universitas Lambung Mangkurat Press, 2010.

[10] Seman, S. H. M. \& Irhamna, Arsitektur tradisional banjar Kalimantan Selatan, Banjarmasin: Lembaga Pengkajian dan Pelestarian Budaya Banjar Kalimantan Selatan, 2011.

[11] Ideham, M.S., Urang Banjar dan kebudayaannya, Banjarmasin: Badan Penelitian dan Pengembangan Daerah Propinsi Kalimantan Selatan dan Pustaka Banua, 2005.

[12] Muchamad, B. N. \& Aufa, N., Rekonstruksi tipologi ruang dan bentuk istana Kerajaan Banjar di Kalimantan Selatan. Dimensi Journal of Architecture and Built Environment, 36(2), pp. 115-126, 2008.

[13] Ven, A. van der., Aantekeningen Omtrent het Rijk Bandjermasin. T.B.G., IX. Verbal 2 Juni 1847, 1, ARA, Jakarta: ANRI (National Archive of the Republic of Indonesia), 1860.

[14] Domenig, G., Religion and architecture in premodern Indonesia, studies in spatial anthropology, Leiden \& Boston: Brill, 2014.

[15] Aqli,W., Anatomi bubungan tinggi sebagai rumah tradisional utama dalam kelompok rumah Banjar. NALAR, 10, pp. 71-82, 2011. 
[16] Ma'rifat, T.A., \& Purwanto, A., Rumah adat tradisional bubungan tinggi. Potensi sebagai obyek wisata sejarah. Kundungga Buletin Pelestarian Cagar Budaya, 1, pp. 1-15, 2012.

[17] No author, Rumah tradisional Banjar Rumah Bubungan Tinggi, Banjarmasin: Museum Negeri Lambung Mangkurat Propinsi Kalimantan Selatan, 1984.

[18] Seman, S., dan Irhamna, Arsitektur tradisional Banjar Kalimantan Selatan, Banjarmasin: Ikatan Arsitek Indonesia Daerah Kalimantan Selatan, 2005.

[19] Burke, H., Ideology and the material culture of life and Death. Historical archaeology, ed. M. Hall \& S.W. Silliman, USA: Blackwell Publishing Ltd., pp. 128-146, 2006.

[20] No author, Rumah tradisional Banjar, Banjarmasin: Museum Negeri Lambung Mangkurat Propinsi Kalimantan Selatan, 1981.

[21] Longhurst, B., et al., Introducing cultural studies, England: Prentice Hall Europe, 2008.

[22] Syamtasiah, I., Kesultanan Banjarmasin pada abad ke-19: ekspansi pemerintah Hindia-Belanda di Kalimantan, Tangerang Selatan: Serat Alam Media, 2012. 